\title{
FIRST RECORD OF APRISTUS EUROPAEUS MATEU, 1980 (COLEOPTERA, CARABIDAE) IN CROATIA
}

\section{Andreja Brigić ${ }^{*}$, Sandra Slivar ${ }^{2}$, Snježana Vujčić-Karlo ${ }^{3}$ \& Mladen Kerovec ${ }^{1}$}

\author{
${ }^{1}$ Department of Biology, Faculty of Science, University of Zagreb, Rooseveltov $\operatorname{trg} 6$, \\ 10000 Zagreb, Croatia \\ ${ }^{2}$ Croatian Environment and Nature Agency, Department for Alien Species, Radnička cesta 80/7, \\ HR-10 000 Zagreb, Croatia \\ ${ }^{3}$ National Museum Zadar, Natural History Department, Medulićeva 1, 23000 Zadar, Croatia
}

Brigić, A., Slivar, S., Vujčić-Karlo, S. \& Kerovec, M.: First record of Apristus europaeus Mateu, 1980 (Coleoptera, Carabidae) in Croatia. Nat. Croat., Vol. 26, No. 2., 321-323, Zagreb, 2017.

Apristus europaeus was recorded for the first time in Croatia. It was found in the dry river bed of the temporary Krčić River (Dalmatian Zagora region), situated beneath the Dinara Mountains. This record represents the southeasternmost distribution border of this species in Europe. Apristus europaeus was sampled with pitfall traps in July 2014. The substrate was composed of boulders, without mosses or algae. Microclimatic conditions were unfavourable for soil invertebrates, since the dry river beds were exposed to intense solar radiation and wind. Our findings show that A. europaeus could quickly recolonize new and unstable habitats, implying that it has a high dispersal capacity. However, this study raises the question of the A. europaeus habitat preference, for in previous studies, it was characterised as a stenotopic hygrophilous species inhabiting the banks of flowing waters.

Key words: Dinara Mountains, Dinaric karst, new record, dry river bed, temporary river

Brigić, A., Slivar, S., Vujčić-Karlo, S. \& Kerovec, M.: Prvi nalaz vrste Apristus europaeus Mateu, 1980 (Coleoptera, Carabidae) u Hrvatskoj. Nat. Croat., Vol. 26, No. 2., 321-323, Zagreb, 2017.

Vrsta Apristus europaeus je zabilježena po prvi put u Hrvatskoj. Pronađena je u suhom riječnom koritu povremene rijeke Krčić (Dalmatinska zagora), smještene podno Dinare. Ovaj nalaz predstavlja najjugoistočniju granicu rasprostranjenja ove vrste u Europi. Vrsta Apristus europaeus sakupljena je pomoću lovnih posuda u srpnju 2014. Supstrat se sastojao od velikog kamenja, bez mahovine ili algi. Mikroklimatski uvjeti su bili nepovoljni za beskralješnjake tla, budući da su suha riječna korita izložena intenzivnom sunčevom zračenju i vjetru. Rezultati ukazuju da A. europaeus može brzo kolonizirati nova nestabilna staništa, što sugerira da ima visoku mogućnost disperzije. Međutim, ovim istraživanjem dovodi se u pitanje stanišna preferencija vrste A. europaeus, koja je u prethodnim istraživanjima karakterizirana kao stenovalentna higrofilna vrsta koja nastanjuje obale tekućica.

Ključne riječi: Dinara, dinarski krš, novi nalaz, suho korito, povremena tekućica

The genus Apristus Chaudoir, 1846 is, in Europe, represented by four species: A. coiffaiti Mateu, 1980, A. europaeus, A. reticulatus Schaum, 1857 and A. subaeneus Chaudoir, 1846 (Kabak in Löbl \& Smetana, 2003). Apristus coiffaiti and A. reticulatus have more restricted distribution ranges than the other two species, occurring in Europe only in the south (KabaK in Löbl \& SMETANa, 2003). The distribution range of Apristus coiffaiti is particularly restricted as it was documented solely for the Greek mainland and Aegean Islands, while the latter species was documented also for Turkey and from Iran to Uzbekistan

*corresponding author, andreja.brigic@biol.pmf.hr 
(ARndt in Arndt et al., 2011). Apristus subaeneus has the widest distribution range of all four species and it occurs in Western (only France), Central (only Hungary) and South-eastern Europe, the Middle East and in the Caucasus region (Kавак in Löвl \& Smetana, 2003). It is the only species of the genus Apristus previously documented for Croatia, in the Mediterranean biogeographical region (regions according to EEA, 2015; NovaK, 1952). Apristus europaeus is distributed in Western and Central Europe, from Great Britain in the north to Portugal in the west and Italy in the east (KABAK in LöBl \& SMEtanA, 2003). This species has now been documented for the first time in Croatia, in the Alpine region. It was found in a dry river bed of the temporary Krčić River (south-eastern part of Croatia), situated beneath the Dinara Mountains. Thus, this record represents the southeasternmost distribution border for this species in Europe.

Specimens of Apristus were identified according to Lompe (2015) and Pershon in MüLler-MotzFELD (2006). All collected specimens are stored in $75 \%$ ethanol and deposited in the collection of the first author (Department of Biology, Faculty of Science, Zagreb).

In total, five individuals of A. europaeus ( 3 females and 2 males) were collected in a dry river bed of the Krčić River, close to the main spring on July 15th, 2014 (HTRS96 N 04876171, E 00486477; Fig. 1a). All specimens were macropterous, and were collected using pitfall traps. The traps (polythene cups, volume $0.3 \mathrm{dm}^{3}$ ) were partially filled with a mixture of ethylene glycol and water (3:2 ratio). A drop of neutrally-smelling detergent was added to the solution to reduce the surface tension. A dark roof was placed above each trap to protect it from the rain. The substrate was composed of boulders, without mosses or algae (Fig. 1b). Substrate temperature of the dry river bed, measured at a depth of $5 \mathrm{~cm}$ with a digital TFA Dostmann thermometer, was high (mean $\pm \mathrm{SD}, 20.21 \pm 1.36$ ), with a maximum of $20.8^{\circ} \mathrm{C}$. A similar pattern was observed for air temperature $(26.55 \pm 0.48)$, with a maximum of $27.3^{\circ} \mathrm{C}$, measured

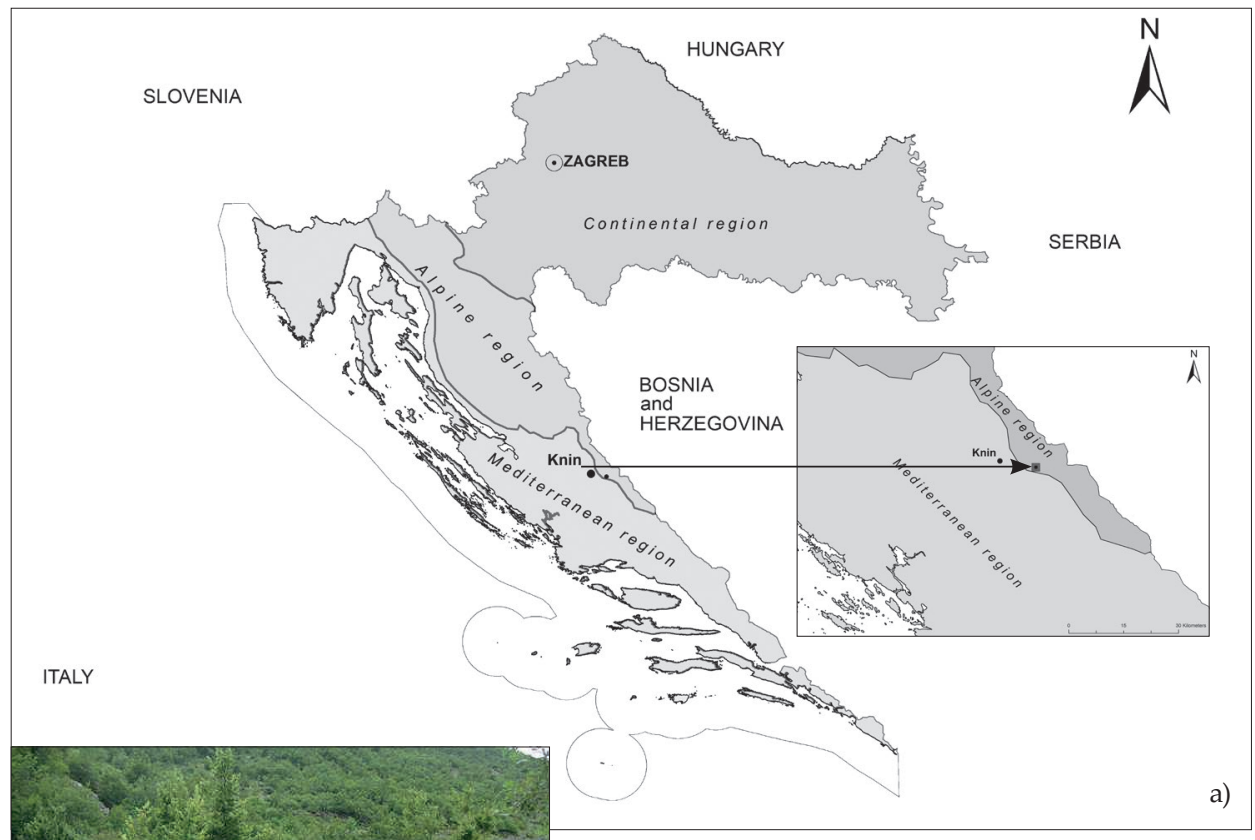

Fig. 1: a) distribution of Apristus europaeus Mateu, 1980 in Croatia (near Knin, Alpine biogeographical region); b) dry river bed of the temporary Krčić River. 
at ground level with a Trotec T200 thermo hygrometer. These measurements were taken during a cloudy day, thus the extremes will be undoubtedly more pronounced during hot and sunny summer days. Dry riverbeds are extreme habitats for soil biota since they are exposed to intense insolation, high temperatures and wind (STEWARD, 2012). Recently, Hoess (2016) reported findings of A. europaeus in the construction edges of a motorway, under the stones. These findings, together with our results, are not in accordance with previously documented habitat preferences for A. europaeus, which suggest that this small sized species inhabits the banks of flowing waters (LukA et al., 2009; Persohn in MüllerMotzfeld, 2006). However, they certainly imply that A. europaeus can quickly recolonize newly established habitats. We do not know whether this species establishes stable populations in such an unstable environment or it uses them at a short temporal scale. What is more interesting, A. europaeus was not recorded in the riparian and karstic habitats along the Krčić River, surveyed intensively in 2014 (with 108 pitfall traps per habitat type, during an 8 month period). Thus it is still unclear what the habitat preferences of this species are. As suggested by Luka et al. (2009) and Persohn in Müller-MotzFeld (2006), this species could be characterised as a stenotopic hygrophilous species. Additionally, we do not know how these habitats are colonised: via flight (since the specimens were macropterous) or by wind [since the species is $3.2-4.0 \mathrm{~mm}$ long and aerial dispersal was documented for several small sized carabid beetles - Thiele, (1977)]. Future studies, involving other trapping methods (e.g. window traps), are necessary to answer these questions.

Apristus europaeus was collected together with other carabid beetle species, e.g. Agonum viduum Panzer, 1796, Elaphropus diabrachys (Kolenati, 1845), Bembidion tetracolum Say, 1823 and Harpalus smaragdinus Duftschmid, 1812, and, which is more interesting, with Apristus subaeneus. Therefore, in the Alpine region of Croatia, the distribution range of $A$. europaeus overlaps with the distribution ranges of A. subaeneus.

\section{ACKNOWLEDGEMENTS}

This study was supported by grants of the University of Zagreb (PL: Ivančica Ternjej, no. 20281233 and 202792).

Received April 13, 2017

\section{REFERENCES}

Arndt, E., 2011: Genus Apristus. - In: Arndt, E., Schnitter, P., Sfenthourakis, S., Wrase, D.W. (Eds.): Ground beetles (Carabidae) of Greece. Pensoft, Sofia-Moscow, 227.

EEA, 2015: Biogeographical regions dataset of European environment agency. Available: http://www. eea.europa.eu/data-andmaps/data/biogeographical-regions-europe-2. Accessed Nov 2015.

Hoess, R., 2016: Interessante Neufunde von Laufkäfern (Coleoptera: Carabidae) aus der Schweiz - 2. Teil. Entomologica Helvetica 9, 53-67.

Kавак, I., 2003: Tribe Lebiini Bonelli, 1810. - In: LöвL, I. \& SmetanA, A. (Eds.): Catalogue of Palaearctic Coleoptera. Apollo Books Stenstrup, 408-439.

Lompe, A., 2015: Gattung Apristus.

Available: http://www.coleonet.de/coleo/texte/apristus.htm. Accessed Jan 2015.

Luka, H., Marggi, W., Huber, C., Gonseth, Y. \& Nagel, P., 2009: Coleoptera, Carabidae: ecology, atlas. Fauna Helvetica, 24. Centre suisse de cartographie de la faune \& Schweizerische Entomologische Gesellschaft Neuchâtel. p. 677.

NovaK, P., 1952: Kornjaši jadranskog primorja (Coleoptera). JAZU, Zagreb.

Pershon, M., 2006: 17. Tribus Platynini Bonelli, 1810. - In: Müller-Motzfeld, G. (Ed.): Die Käfer Mitteleuropas. Vol. 2. Adephaga 1. Carabidae (Laufkäfer). Corrected version of the 2. edition. Elsevier, München, 442-475.

Steward, A., Steward, A. L., von Schiller, D., Tockner, K., Marshall, J. C. \& Bunn, S. E., 2012: When the river runs dry: human and ecological values of dry riverbeds. Frontiers in Ecology and the Environment 10, 202-209.

Thiele, H. U., 1997: Carabid beetles in their environments. Springer-Verlag, Berlin. 